\title{
Brand Performance Analysis of Selected Casual Dining Restaurants In the Philippine's National Capital Region: Basis for Proposed Strategic Brand Mechanism Model
}

\author{
DR. MICHAEL BHOBET B. BALUYOT ${ }^{1}$, DR. CRISTINA N. CALUZA ${ }^{2}$ \\ ${ }^{1}$ College of Industrial Technology, Food and Apparel Technology Department, TECHNOLOGICAL UNIVERSITY OF \\ THE PHILIPPINES MANILA, PHILIPPINES. E-mail: michaelbhobetbaluyot@yahoo.com \\ ${ }^{2}$ School of Hotel, Restaurant and Institution Management, DE LA SALLE COLLEGE OF ST BENILDE, PHILIPPINES. \\ E-mail: cristina.caluza@benilde.edu.ph
}

\begin{abstract}
Sustainability issues for the Philippine casual dining restaurants have been a widespread problem in the current condition of the pandemic. This paper aimed to propose a business approach, with brand standardization and recalibration, to be able to succeed competently in the market. In order to ensure that customer attitudes fulfil their satisfaction and desire, different drivers of brand success, such as marketing, innovation, service qualities, and corporate social responsibility, are essential. A quantitative-descriptive approach was employed with a Cronbach's alpha coefficient yielded a value of 0.982 with 510 respondents located in the National Capital Region with 46 survey questions. The analysis was done using the Spearman Rho Correlation and Analysis of Variance (ANOVA). The findings revealed that there is no significant relationship between the drivers of brand performance and customer attitudes towards brand preference. Furthermore, the findings have shown that the null statement of the large disparity between the customer profiles was rejected and said that at least one of the two samples has a substantially different meaning. The study depicted a brand standard mechanism model which composed of six brand dimensions, namely Brand Management, Brand Service Performance, Brand Safety Protocols and Sanitation, Brand Technical and Operational Design, Brand Menu Selection and Pricing, and Brand Awareness and Sustainability as part of Strategic Brand Mechanism for Casual Dining Restaurants. It is concluded that the well-being and hygiene of casual dining restaurants have been the most difficult in light of the current standard customer support and satisfaction. It is also inferred that the preferences and happiness of the consumer impact.
\end{abstract}

Keywords: Brand Performance; Casual Dining Restaurants; Brand Mechanism; Brand Preference.

JEL Classification: C1, L2, M3

Received: June 12, 2021

Accepted: September 01, 2021 


\title{
Análisis del Rendimiento de la Marca de una Selección de Restaurantes de Comida Informal en la Región de la Capital Nacional de Filipinas: Bases para la Propuesta de un Modelo de Mecanismo Estratégico de Marca
}

\author{
DR. MICHAEL BHOBET B. BALUYOT' ${ }^{1}$, DR. CRISTINA N. CALUZA ${ }^{2}$ \\ ${ }^{1}$ College of Industrial Technology, Food and Apparel Technology Department, TECHNOLOGICAL UNIVERSITY OF \\ THE PHILIPPINES MANILA, PHILIPPINES. E-mail: michaelbhobetbaluyot@yahoo.com \\ 2 School of Hotel, Restaurant and Institution Management, DE LA SALLE COLLEGE OF ST BENILDE, PHILIPPINES. \\ E-mail: cristina.caluza@benilde.edu.ph
}

\begin{abstract}
RESUMEN
Los problemas de sostenibilidad de los restaurantes de comida informal filipinos han sido un problema generalizado en la condición actual de la pandemia. Este trabajo tiene como objetivo proponer un enfoque empresarial, con la normalización y recalibración de la marca, para poder tener éxito de forma competente en el mercado. Para que las actitudes de los clientes cumplan con su satisfacción y deseo, son esenciales los diferentes impulsores del éxito de la marca, como el marketing, la innovación, las cualidades del servicio y la responsabilidad social corporativa. Se empleó un enfoque cuantitativo-descriptivo con un coeficiente alfa de Cronbach que arrojó un valor de 0,982 con 510 encuestados ubicados en la Región Capital Nacional con 46 preguntas de la encuesta. El análisis se realizó mediante la correlación Rho de Spearman y el análisis de varianza (ANOVA). Los resultados revelaron que no existe una relación significativa entre los impulsores del rendimiento de la marca y las actitudes de los clientes hacia la preferencia de la marca. Además, los resultados han demostrado que se rechaza la afirmación nula de la gran disparidad entre los perfiles de los clientes y se dice que al menos una de las dos muestras tiene un significado sustancialmente diferente. El estudio ha representado un modelo de mecanismo estándar de marca que se compone de seis dimensiones de marca, a saber, gestión de marca, rendimiento del servicio de marca, protocolos de seguridad y saneamiento de la marca, diseño técnico y operativo de la marca, selección de menús y fijación de precios de la marca, y concienciación y sostenibilidad de la marca como parte del mecanismo estratégico de marca para los restaurantes de comida informal. Se concluye que el bienestar y la higiene de los restaurantes de comida informal han sido los más difíciles a la luz del actual estándar de apoyo y satisfacción del cliente. También se infiere que las preferencias y la felicidad del consumidor impactan.
\end{abstract}

Palabras clave: Desempeño de la marca; Restaurantes de comida casual; Mecanismo de la marca; Preferencia de la marca.

Clasificación JEL: C1, L2, M3

Recibido: 12 de Junio de 2021

Aceptado: 01 de Septiembre de 2021 


\section{Introduction}

One of the sectors impacted by the pandemic is the multinational food and beverage market. The Jacksonville (2020) study shows that COVID-19 has influenced the food and beverage industry in North America, Europe, Asia-Pacific, and the globe. The new normal has been recognized by the global community as adapting to the pandemic climate. As a result, the food services industry is having problems with the requisite brand mechanism, which can only be complemented by the government's current environment and standards. According to Sharma et al. (2020), the market repercussions are clear: serious revenue decline, a large number of laid-off jobs, and several firms already making their permanent closure decisions.

Verdict (2020) provides an effective evaluation of foodservice providers from the COVID-19 outbreak. The evaluation indicates that a catastrophic effect on operators is required of the pandemic. The majority of respondents believed that $44 \%$ had led to many foods' operators' loss and lengthy recovery periods, and $28 \%$ thought that their effect was extreme but lasted only a few months, followed by $15 \%$ who felt that the impact was severe and led to a very long time after the pandemic, poor market demand. Telukdarie \& Mohlala (2020) also cited the global food and beverage industry as being segmented on the basis of a COVID-19 impact study on the competition in the food and beverage industry on-line food chain and offline food chain. COVID-19 consequences involve food chain offline, which is completely sealed restaurants and cafes in locations like in the Americas, Europe, the Asia-Pacific region, and elsewhere. The current scenario pressures the hospitality sector, especially the foodservice industry, to develop ambitious strategic strategies to solve and support the global economic crisis. This paper provides a recommendation for how to overcome the complexities of the New Normal. This exceptionality must be investigated in order to assess its significance and to complement the industry competently. Management thus faces obstacles, and its versatility must be sufficient to predict and satisfy the diverse demands of its clients. Businesses must also carry out activities such as recruiting personnel, managing staff, setting expectations, and serving clients. All these mentioned indicators will undergo modification because of the new normal standards and protocols in ensuring the safety and security of all the key players in the industry and meeting the brand preference of the consumers.

Vu et al. (2017) point out that environmental or sustainable growth has become more and more an agenda for multinational organizations and industry groups. Over this era, several efforts have been made to incorporate the principle of sustainability. In this context, sustainability is described as "to satisfy our requirements without losing the potential of future generations to meet their own needs" (Hitchcock and Willard, 2009 cited by Vu et al., 2017)

With this in mind, companies have demonstrated a strengthened interest in starting corporate responsibility and marketing campaigns as society progresses to highlight environmental concerns. Social and marketing combines not only the economic success and happiness of a company, but also the ethical or green policies of a company (Nowak et al., 2015). Eco-efficiency thus requires delivery and manufacture of materials while at the same time minimizing resources consumption and resulting environmental impacts. Trends show that the corporate sector has begun to gain social responsibility and environmental awareness to help the company boost its competitive edge. In addition, not only have the organizational and institutional stages influenced the social and environmental transition of organizations but indeed its own internal traditions, convictions, and principles (Chan et al., 2012 Nuncio et al, 2020). Finally, the social and environmental policies for ecosystems, population, and enterprises in the food services industry will lead to win-win status.

The promotion of green policies in restaurants requires a new strategy to improve their environmental and financial efficiency and to promote greater benefits ( $\mathrm{Hu}$ et al., 2010). Recent developments in green cuisine standards, green consumption, and movement towards sustainable, natural, and low carbon food products have arisen (Namkung and Jang, 2013).

Previous reports have introduced different metrics to assess service efficiency in the new normal in the hospitality sector specifically. Kumar \& Chachal (2017) mentions that number of studies 
suggesting the crucial successful aspect of every service company in the era of globalization and the consistency of tickets on the market have been performed. These scales also underline the significance of person or group service dimensions: quality of the physical world, interactional quality, and outcome quality (Namkung and Jang, 2007). Researchers have suggested that these metrics be related to primary outcomes factors, such as consumer satisfaction and behavioral intentions, in several experiments.

Although such interventions are commendable, there is not much research available that provides a thorough analysis of the influence on brand success, particularly in this new normal situation, of marketing practices, creativity, CSR, and service quality. Harrington et al. (2014); Jang and Park (2011); Trace (2014), as cited by DiPietro (2017) posit that the types of research on foodservice over the past 30 years have been focusing on hospitality literature together with the academic literature. Food services promotion, innovation and protection and health is mostly focused on restaurant divisions, operation, quality of service, restaurant finances. First, studies on corporate social responsibility (CSR), recycling, and menu labeling began to emerge. This research also leads to literature that focuses on marketing, sustainability, CSR, creativity, and food security relationships. In the midst of this issue, it would be useful to know if a series of shared problems might hinder the capacity of the foodservice industry to cope with today's uncertainties, given that a similar collection of problems can lead to solutions across the industry.

This paper aimed to propose a business approach, with brand standardization and recalibration, to be able to succeed competently in the market. With this statement from the scientific evidence in order to ensure that customers behaving and attitudes fulfill their satisfaction and desire, particularly in this new normal situation, different drivers of brand success, such as marketing, innovation, service qualities, and corporate social responsibility, are essential. Consumer loyalty and behavioural aims were fulfilled by the success levels in servicing clients, so the measurement of service quality by matching customer preferences with perceived performing results was highly sensitive both from marketers and researchers.

The use of descriptive correlational studies has been employed by Filipino researchers which make it applicable in this study (Ahorro, et al, 2021, Charernnit, et al, 2021, De Souza, et al, 2021, Lopez, et al, 2021, Magulod Jr, 2017, Magulod Jr, 2019, Magulod, et al, 2021, Magulod, et al, 2020, Nuncio, et al, 2020). The research aimed to evaluate the relationship between the drivers of brand performance and the challenges encountered by the casual dining restaurants in the National Capital Region during the pandemic to propose a strategic brand mechanism model.

\section{Drivers of Brand Performance}

Recent studies have contributed to a better indication of the efficacy of brand-related operations of an enterprise, as quoted by lyer (2020). The brand and promotion managers and senior managers were interested in this report. Based on the findings, many internal and external influences affected the brand performance. Baumgarth and Schmidt note in 2010 that brands are symbolically linked to greater levels of brand identification, participation, and citizenship, as cited by lyer (2020). Internal branding is apparent from the viewpoint that intellectual capital is one of the organization's most valuable tools.

In 2000, Akinova explained the performance of industry to be measured for two performance types: the sector that covers conditions, competition, and financial indicators, and the environment that includes product and service performance in the environment. The business outlook is focused on the emergence of new local and global markets, high investment returns, and increased market shares (Pujari et al., 2003). The viewpoint on environmental performance focuses on the general elimination of environmental impacts of goods and services and an improved environmental profile (Pujari et al., 2003). Empirical analysis has analyzed the business and environmental success predictors. In the hospitality industry, the introduction of new services and goods to maximize profitability illustrates revenues and profit-based efficiencies, as sales volume demonstrates market 
strength (Ottenbacher, 2007). The green image and competitive advantage, in turn influencing business and environmental efficiency, can be affected by innovation (Chiou et al., 2011). However, if the financial results did not change, consequently the use of environmental marketing practices would face a problem. However, within the market and eco-performance sense, if food companies are considered to be beneficial to our society and our climate, they can participate in sustainable green-based activities (Pujari et al., 2003). Research is also important to further explore the effects of restaurant-based creativity and environmental marketing based on both market and ecoperformance (Chiou et al., 2011).

\subsection{Corporate Social Responsibility}

Pan et al. (2020) has found that corporate social liability is more complicated in times of financial crisis and corporate value in the area of sustainability, social responsibility, and shareholders and economic success. The findings are more controversial. Today, the philosophy of CSR or corporate social responsibility reflects the interests of company organizations in the context of the effect of their operations on clients, vendors, workers, owners, societies, and the community. This provision illustrates that companies must follow the laws and take voluntary steps to enhance the well-being of their workers, families, and the broader communities and society as a whole.

The word CSR is used in an interchangeable fashion with numerous other terms such as business principles, corporate governance, company responsibility, and sustainability, according to the Business for Social Responsibilities (BSR). In BSR, all these words mean 'to achieve trade success in ways that uphold ethical standards and the environment' According to BSR, CSR is being comprehensively studied by socially conscious organizations and will cover numerous CSR "issues," such as corporate ethics, participation in the society, the economy, governance, and transparency, human rights, understanding of consumer dynamics and reactions to business activities.

The way thousands of people live, work, shop, and communicate in a way that seems to be evolving by the minute, according to Peters (2020). This uncharted terrain of a global pandemic has sparked terror and hope: it cuts off-trade and encourages innovation; it has compelled us to stay apart while pushing us closer together. In the sense of fear, insecurity, and anxiety, corporations that emerge as leaders realize the fundamental truth that corporate citizenship does not have to be abandoned. The time has come to double.

\subsection{Environmental Marketing}

Firms' modification in the way they work with the world has modified their competition practices, bringing in adaptive business policies with regard to civil, legal, and economic factors. There is an increased focus on the relationship between the atmosphere and the priorities of businesses as organizations are looking to strengthen their economic viability (Fraj-Andres et al., 2009). This gives rise to environmentalism, which customers and accommodates environmental expectations (Peattie, 2001).

More recently, environmentally sustainable marketing has come to be regarded as a term that goes beyond offering just green goods orientation from conventional management to the environment is needed (Fraj-Andrés et al., 2009). We choose this strategy because it involves not just process improvements but also changes in how we communicate, as well as developing green ideas and implementing environmentally safe (Fraj-Andrés et al., 2009, Magulod et al, 2021). Environmental marketing is referred to as nature-oriented approaches, policies, strategies, and procedures that a firm implements to target customer thinking and boost an organization's standing in relation to ethical behavior, as well as it targets the dynamics between different companies (Baker and Sinkula, 2005).

According to an idea generated since the introduction of renewable and recycled commodities, environmental marketing has been defined as strategic (maintains the use of recycled or greener products, construction, and logistics and investments for ecologically efficient product development) 
(launch of eco-friendly product lines, green advertising, sponsorship of environmental events and use of eco-labels). However, it has also shown that environmental marketing is advantageous in terms of lower prices, as well as product differentiation. Operational and competition efficiency was also improved because of it (Fraj-Andrés et al., 2009).

Another important research subject in the context of restaurants' business activities is sustainability, environmentally friendly practices, and CSR. For well over a decade, in regards to CSR and the business environment and customer expectations, this has been an under-discussed subject that plays an important role in operations and restaurant operations, and guests (DiPietro et al.). This study indicates that diners are getting more conscious of the environmental challenges every day, and they look at these questions in restaurants they visit. Customers are usually involved in sustainable restaurant activities but aren't prepared to compensate for them. The two common focuses of current study studies are how restaurants should better advertise themselves and what they really use for marketing themselves. Another result, stated in previous studies, is that workers can know how to convey green knowledge to consumers. Using gender distinctions, the researchers noticed that involved women were far more likely to practice sustainable activities than were those who identified as being highly educated (DiPietro et al., 2013; DiPietro and Gregory, 2012; Dutta et al., 2008).

\subsection{Innovation}

It is definiteness to the point that innovative services or goods are created by humans, utilizing customers' information and technology and rivalry (Hull and Lio, 2006). Green innovation is all about developing facilities and/product emission reduction and electricity savings, as well as ecofriendliness, environmental conservation (Chang, 2011). The new product, service, and program creation method are focused on flexibility, intent, and potential for long-term success (Hull and Lio, 2006).

Green innovation would help materials to be efficiently and effectively used to convert nonfactory waste into services or selling, reducing the total expense for influences market suppliers to do so that the transfer of non-saleable content to sales is made. If consumers perceive that the products have environmental advantages, such products would certainly have a higher overall value for the company (Ar, 2012). The invention process can be split into two stages: exploration and validation. The first is to apply technological advances to facilities, goods, or procedures or to manufacturing processes used in making products. Furthermore, operational advances are related to organizational processes and management functions (C.J. and J.P., 2008). This division puts an emphasis on sustainable innovation, highlighting the potential in the hospitality industry.

Close cooperation with customers at the design, preparation, and final testing stages is a key element for successful innovation. Companies who have used strategic alliances with other companies or suppliers, where possible, have strengthened their innovative capabilities and, ultimately, enhanced their effectiveness in implementing them. The usage of more strategic human resources strategies that were related to business design, the establishment of an imaginative culture, and facilitation of development or entrepreneurship was a final core competency popular to companies with innovation performance. (Ottenbacher and Harrington, 2013)

The results of technical progress are highly affected by disrupting economies, shifting the relative value of capital, challenges corporate learning, and shifts in productivity. New technologies will either improve skills, expand on established know-how, reinforce current roles or disrupt skills, outdated existing know-how and make entrants' technologically superior competitors feasible. Technological advancement provides entrants with resources to develop new companies, and as a source of benefit for incumbents, competition roles are created. Technological breakthrough often causes confusion and risks for incumbents, as the results can only be expected imperfectly. The effect of technologies will not be understood until it is too late to effectively contend with emerging entrants for incumbents that use older know-how. Gambling at an early stage may threaten the 
longevity of an incumbent if the invention does not become a powerful one. The fundamental technology and technical advancement will therefore have a significant impact on the strategic dynamics and growth of corporate populations. Laužikas, M. et al. (2016) support this by stating that advances are strongly connected with differentiation and market positioning as they bring the strategic edge and moving advantage within the food sector.

Accessibility, with the latest advances and adoptions in targeting larger customer markets via social network services, social company portals, and smartphone apps, is a core component in the foodservice industry (Ar, 2012). In addition, restaurants will contribute to different experiences, preferences, and interests for consumers through the usage of existing technologies in other areas and expand new markets; (Harrington and Ottenbacher, 2013). A restaurant has changed its conventional function, which is emphasized on the menu. Innovative market strategies to improve attractiveness and usability have been embraced by restaurants (Harrington and Ottenbacher, 2013). This study indicates that creativity will help foodservice companies stay competitive and have comparative advantages (Ottenbacher and Harrington, 2009).

DiPrieto (2017) points out that a study of the role of ICT in restaurant operations is linked to operational efficiency. He emphasized again in his report that there would be little efficiency benefit if the technologies focused on financial and service efficiency were not incorporated into the UK's three-star hotel operations. In analyzing the application of technologies in restaurants, DiPrieto (2017) quoted Ruiz-Molina et al. (2014) and identified additional applications. DiPrieto (2017) has determined through the research that technology will contribute from inventory outsourcing to event control, to data profiling, to client experience management through to the whole reconstruction process.

The main principles drawn from these innovation testing trials are that businesses must continually aim to develop their service and product systems through easing replication by others, thus reducing the comparative benefit of innovation. In addition, a multidisciplinary, pragmatic strategy to achieve the most successful innovation is needed. It's no novelty to be reactive in foodservice. Food protection and product health are also a field of foodservice creativity. Food protection analysis and well-being of menu products have been of concern for some time, but late interest has been growing due to enhanced consumer awareness of food safety and public health concerns correlated with obesity. The following segment addresses common issues relevant to these research fields.

\subsection{Service Quality}

Giving a company the opportunity to retain its position in a dynamic sector, the degree of service quality in restaurants has greatly affected current research on the effect of consumer perceptions towards brand name on a variety of backgrounds of service quality. In earlier studies, the primary assumption is that standards of service such as physical environments, interactional quality, and quality of outcomes are significant since they have a positive impact on satisfaction. Brands are critical for consumers as well as service quality. Brands are now part of our lives (Bhatti, Parveen, \& Arshad, 2011). Some customers, according to Zhou and Wong (2008), rely more on brand quality than on product quality and make the brand more relevant than the quality of the product. For example, consumers don't take into consideration all the characteristics of restaurants at dinner but often pick a restaurant focused on a broad approach towards a special brand of restaurants. Therefore, it is important to consider the views of consumers towards products. However, several of the preceding research focused more on restaurant satisfaction.

Previous researches have taken a series of steps, including LODGSERV, DINESERV TANGSERV, and DINESCAPE, in an attempt to quantify service efficiency directly in the entertainment industry (Ryu \& Jang, 2008). These levels also emphasize the significance both separately and jointly of service dimensions: the consistency of the physical setting, the contact quality, and the quality of performance. In several researchers, the links between these metrics, such as consumer loyalty and 
behavioral intentions, have been suggested and verified by the researchers. In the 2009 study by Han and Ryu, a physical setting of high quality (with the use of decoration and objects, a space-like arrangement, and environmental conditions) was seen to provide greater satisfaction for customers. In Kim and Ok's (2010) research, interactional is affected by the happiness of the client. Namkung and Jang (2007) have explored the function of food quality in forecasting consumer loyalty, in particular appearance, range of menus, taste, freshness, and temperature. Their studies reveal crucial connections between consumer loyalty and behavioral intentions, and quality of food.

With respect to the level of operation, quality of product, environment, and price, the restaurant from fast foods to fine dining has important positions. The menu and cleanliness have contributed to the standard of service (DiPrieto, 2017).

Figure 1 Drivers of Brand Performance in the Casual Dining Restaurants in the New Normal

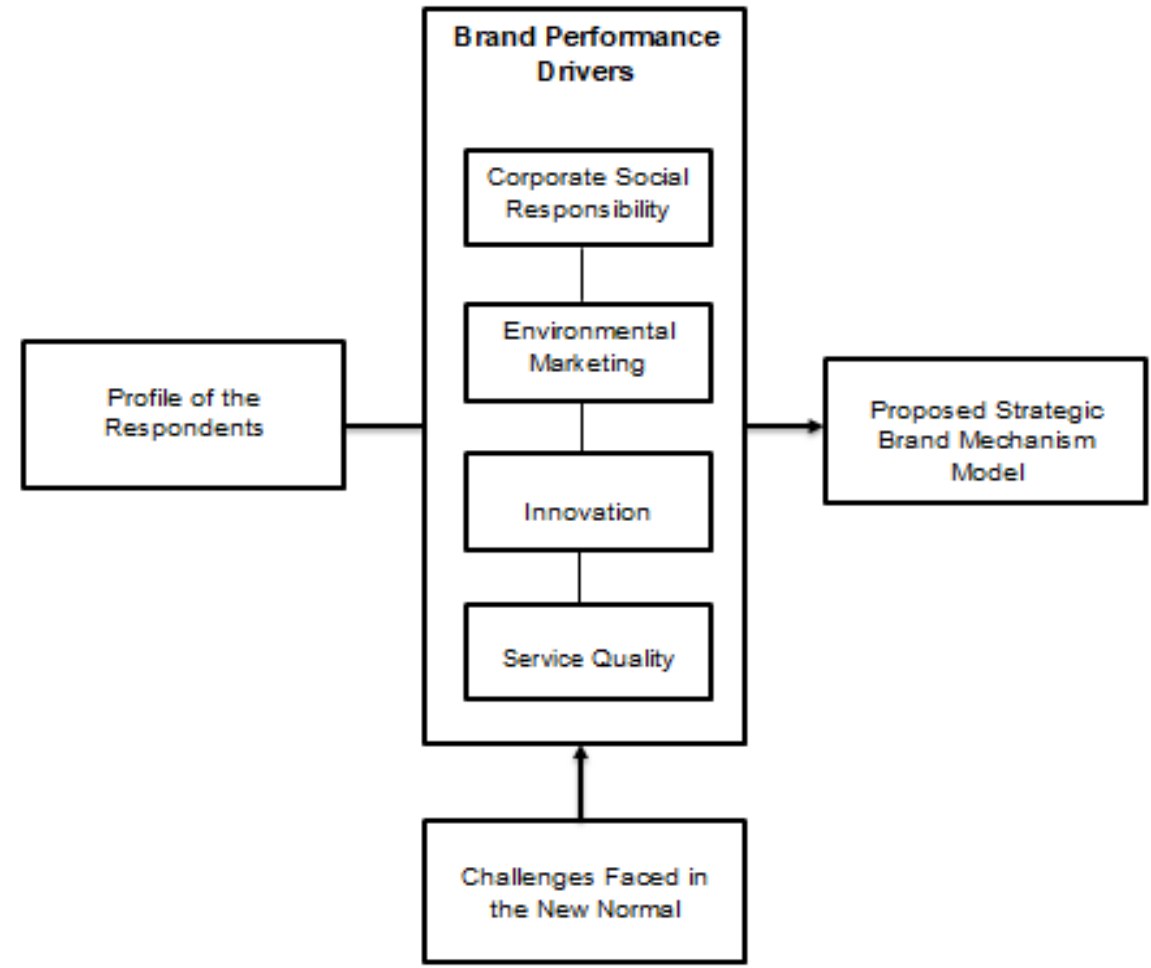

Source: Anchored and Modified in the frameworks of Kim et al. (2017) and Hwang (2011)

The different drivers of brand performance used in this study are the modified conceptual framework which consists of corporate social responsibility, marketing, innovation, and service quality as antecedents. According to Gheribi (2018), Corporate Social Responsibility is a strategy that promotes balanced growth through providing economic, social, and environmental benefits to all stakeholders. Social corporate social responsibility encompasses four types of social tasks: economic, legal, ethical, and philanthropic, which make up the total CSR. Marketing, on the other side, would have an effect on foodservice quality and valuation because it allows stakeholders to properly comprehend their prospects (Namkung and Jang, 2013). As part of the campaign evaluation of this report, tactical and strategic marketing will be included.

The degree to which businesses create new services or products by integrating consumer, technology and competitors' expertise is defined as innovation, according to Hull and Lio, 2006. Innovation In this report, the marketing appraisal would include technical and organizational innovation. Service quality is typically distinguished by the customer's sense of relative dominance and inferiority of the supplier, as well as the customer's overall attitude to the company (Su and Linderman, 2016). Service quality comprises the quality of the physical environment, interactional, and outcome. The identification of the problems posed by casual dining restaurants in the modern mainstream is often seen in the philosophical context. Identifying these issues would be critical in 
developing solid and appealing solutions and interventions to support casual dining brands in the National Capital Region to survive and recover. The study also projects to recommend a proposed strategic brand mechanism for sustainability in the new normal.

\section{Assessment of Casual Dining Restaurant Customers Rating on The Drivers of Brand Performance}

\subsection{Corporate Social Responsibility}

Presented in Table 2 is the descriptive summary of the assessment of the casual dining restaurant customer's in terms of corporate social responsibility as one of the drivers of brand performance. As shown in the table, the result shows that among the drivers for brand performance among casual dining restaurants, the highest is the indicator under Ethical and Legal CSR which states that "The establishment promotes and engages with community development and community service. "and "Both goods of the establishment follow regulatory specifications" with an average mean of 4.45, with a verbal interpretation of Very Satisfactory. The finding denotes that all the indicators in the corporate social responsibility driver are "Very Satisfactory," which means that the casual dining establishment follows basic requirements for brand performance.

Table 1 Descriptive Summary of the Assessment of the Casual Dining Restaurant Customers in terms of Corporate Social Responsibility

\begin{tabular}{cccc}
\hline $\begin{array}{c}\text { DIMENSIONS OF } \\
\text { CORPORATE SOCIAL } \\
\text { RESPONSIBILITY }\end{array}$ & $\begin{array}{c}\text { WEIGHTED } \\
\text { MEAN }\end{array}$ & $\begin{array}{c}\text { STANDARD } \\
\text { DEVIATION }\end{array}$ & INTERPRETATION \\
\hline ECONOMIC CSR & 4.20 & 0.66 & VERY SATISFACTORY \\
LEGAL CSR & 4.35 & 0.64 & VERY SATISFACTORY \\
ETHICAL CSR & 4.35 & 0.61 & VERY SATISFACTORY \\
PHILANTHROPIC CSR & 4.32 & 0.60 & VERY SATISFACTORY \\
\hline
\end{tabular}

According to He and Harris (2020), the real, genuine CSR would enhance its consumer and the general public's relationships, given that during the current crisis, they have developed high hopes for their contributions in the fight against the virus, mostly from their favorable products. Consumers will be proud to have their workers contribute funds and supplies through the disaster. At this time of crisis, the connection formed between brand and customer could be more meaningful and durable than in "peaceful" days. Thus, the Covid-19 pandemic presents businesses with fantastic resources to work aggressively on their CSR initiatives and agenda. The pandemic has, however, driven many enterprises out and perhaps on the verge of crashing. It is increasingly necessary, particularly as resources are scarce and the sustainability of companies is threatened to be seen to make certain corporations more ethically and socially responsible.

In 2015, Kim, Park, and Ryu focused on legal sources as key influences underlying market environments, management philosophies, corporate governance processes, and investment security mechanisms. These considerations influence long-term and large investment decisions in particular. Study findings indicate that long-term investment choices have the legal origin and potential benefit of the civil law regime. These elements were generally assumed to be equivalent in terms of corporate governance to the civil law structure.

\subsection{Environmental Marketing}

Presented in Table 2 is the descriptive summary of the assessment of the casual dining restaurant customer's in terms of environmental marketing as one of the drivers of brand performance. As shown in the table, the result shows that among the drivers for brand performance of casual dining restaurants in terms of Environmental Marketing, the highest indicator is under tactical marketing, which states that "The establishment use eco-labels to promote environment-friendly atmosphere." 
with an average mean of 4.44 and with a verbal interpretation of Very Satisfactory. The finding denotes that all the indicators in the Environmental Marketing driver are "Very Satisfactory," which means that the casual dining establishment follows basic requirements for brand performance.

Table 2 Descriptive Summary of the Assessment of the Casual Dining Restaurant Customers in terms of Environmental Marketing

\begin{tabular}{cccc}
\hline $\begin{array}{c}\text { DIMENSIONS OF } \\
\text { CORPORATE SOCIAL } \\
\text { RESPONSIBILITY }\end{array}$ & $\begin{array}{c}\text { WEIGHTED } \\
\text { MEAN }\end{array}$ & $\begin{array}{c}\text { STANDARD } \\
\text { DEVIATION }\end{array}$ & INTERPRETATION \\
\hline $\begin{array}{c}\text { STRATEGIC } \\
\text { ENVIRONMENTAL MARKETING }\end{array}$ & 4.26 & 0.70 & VERY SATISFACTORY \\
$\begin{array}{c}\text { TACTICAL } \\
\text { ENVIRONMENTAL MARKETING }\end{array}$ & 4.37 & 0.66 & VERY SATISFACTORY \\
\hline
\end{tabular}

According to Militi (2021), most companies face three issues in the marketing mix: offering nonessential goods and services, communicating with customers, and touching the right target audience. This describes how it is difficult to get into the market with new brands, basic goods being pricey, and offering promotions to attract customers, with advertising is the most difficult for new brands. Until marketing to the customer, have a humanitarian message to improve the brand and boost postCOVID loyalty. To be effective in these tough times, companies would need to move toward integrated marketing, adopt a competitive marketing approach and make an emotional connection with their customers. "It requires a heavy stomach and a firm backbone," but creating consumer satisfaction is crucial in all marketing settings and maybe more important than it is today.

\subsection{Innovation}

Presented in Table 3 is the descriptive summary of the assessment of the casual dining restaurant customer's in terms of innovation as one of the drivers of brand performance. As shown in the table, the result depicts that among the drivers for brand performance among casual dining restaurants, the highest indicator under Innovation states that "The organization has a firm dedication to the usage of emerging technology and tools to strengthen the management of the company." with an average mean of 4.65, has an equivalent verbal interpretation of Excellent. The finding denotes that the majority of the indicators in an Innovation are "Excellent," which means that the casual dining establishment is outstanding in terms of brand performance.

Table 3 Descriptive Summary of the Assessment of the Casual Dining Restaurant Customers in terms of Innovation

\begin{tabular}{lcccc}
\hline $\begin{array}{c}\text { TECHNOLOGICAL } \\
\text { ORGANIZATIONAL } \\
\text { INNOVATION }\end{array}$ & AND & $\begin{array}{c}\text { WEIGHTED } \\
\text { MEAN }\end{array}$ & $\begin{array}{c}\text { STANDARD } \\
\text { DEVIATION }\end{array}$ & INTERPRETATION \\
\cline { 2 - 5 } & 4.51 & 0.70 & EXCELLENT \\
\hline
\end{tabular}

The result supports the claim of Laužikas, M. et al. (2016) that innovations are highly related to differentiation and positioning in the market because they give competitive advantage and firstmover advantage in the food industry. Likewise, DiPrieto (2017) cites that in assessing the use of technology in restaurants, it was found that technology can help the entire process of restaurant operation and management, from outsourcing of products to incident management to tracking customer profiling data and customer relationship management.

\subsection{Service Quality}

Presented in Table 4 is the descriptive summary of the assessment of the casual dining restaurant customer's in terms of service quality as one of the drivers of brand performance. As shown in the table, the result shows that among the drivers for brand performance, all the indicators under 
Service Quality have accumulated an average mean of more than 4.51, which has an equivalent verbal interpretation of Excellent. The finding denotes that the casual dining establishments are outstanding in terms of brand performance for service quality.

Table 4 Descriptive Summary of the Assessment of the Casual Dining Restaurant Customers in terms of Service Quality

\begin{tabular}{cccc}
\hline $\begin{array}{c}\text { DIMENSIONS OF SERVICE } \\
\text { QUALITY }\end{array}$ & $\begin{array}{c}\text { WEIGHTED } \\
\text { MEAN }\end{array}$ & $\begin{array}{c}\text { STANDARD } \\
\text { DEVIATION }\end{array}$ & INTERPRETATION \\
\hline PHYSICAL QUALITY & 4.64 & 0.73 & EXCELLENT \\
INTERACTIONAL QUALITY & 4.57 & 0.67 & EXCELLENT \\
OUTCOME QUALITY & 4.55 & 0.66 & EXCELLENT \\
\hline
\end{tabular}

Based on the list of a variety of studies relating to the income from operation by Danish Habib and Attiq (2020), literature on the effect on consumer reaction and efficiency of employee's relevant attitudes is minimal. They attach value to the analytical paradigm and evaluate the perceptual and emotional dimensions of consumer reactions and service empirically. The study of DiPrieto (2017) found that restaurants for fast foods can strive to maintain their success in terms of convenience/efficiency and value/quality. From the study, it was discovered that casual restaurants worked well for the guests when the guest and the restaurant were associated in an emotionally related way. The characteristics of the restaurant, which applied to customers that were extremely satisfactory, were examined by DiPrieto (2017) and Jang (2008). The results were reflected in other factors, namely that the standard of food and service along with the cloak, such as seating, backdrop, and indoor architecture, was critical. According to the study of Kim et al. (2014), the understanding of time in restaurants has also been studied, particularly without a certain number of guests waiting in line. The analysis showed that it was lower than the real wait times by utilizing the menu and menu details as a distractor for the visitors. Technology often plays an important role in allowing restaurants to call up people to place their names on the waiting list for a restaurant order. The analysis also indicated that the usage of smartphone devices is expected in future research today as the number of restaurant rises.

\section{Relationship of Drivers of Brand Performance Towards Brand Preference}

The study used the correlation matrix utilizing Spearman's Rho Correlation Coefficient to test the null hypothesis asserting there is no significant relationship between the drivers of brand performance and customer attitudes towards brand preference in terms of Corporate Social Responsibility Practices, Marketing Practices, Innovation, and Service Quality as shown in the table.

Table 5 Relationship of Drivers of Brand Performance towards Brand Preference

\begin{tabular}{ccc}
\hline Variable & $\begin{array}{c}\text { Spearman's Rho Correlation } \\
\text { Co-efficient }\end{array}$ & $\begin{array}{c}\text { Significance } \\
\text { (2-tailed) }\end{array}$ \\
\hline $\begin{array}{c}\text { Corporate Social Responsibility } \\
\text { Practices } \\
\text { Marketing Practices }\end{array}$ & 0.351 & 0.790 \\
Innovation & 0.119 & 0.896 \\
Service Quality & 0.136 & 1.000 \\
\hline
\end{tabular}

Note: NS - statistically non-significant with $p>0.05-$ level of significance

As can be seen, the values computed $\mathrm{P}(\mathrm{T}<=\mathrm{t})$ two-tail were all greater than the level of significance $\alpha$ equal to .05, and therefore the researcher accepted null hypothesis (Ho), thus concluded that statistically non-significant relationship between the drivers of brand performance 
and customer attitudes towards brand preference in terms of Corporate Social Responsibility Practices, Marketing Practices, Innovation and Service Quality given in the study. This table presents the findings of the study for each problem identified and under investigation. The results of both descriptive and inferential statistical tests are presented and explained.

\section{Significant Differences Between and Among Respondents Profile}

The study used the Analysis of Variance (ANOVA) to test the null hypothesis asserting there is a significant difference between the drivers of brand performance when grouped according to respondent's profile.

Table 6 Significant Differences Between and Among the Respondents Profile

\begin{tabular}{|c|c|c|c|c|c|c|c|}
\hline ANOVA & & & & & & & Interpretation \\
\hline & SS & $d f$ & MS & $F$ & $\begin{array}{r}P- \\
\text { value }\end{array}$ & F crit & \\
\hline $\begin{array}{l}\text { Betwee } \\
\text { n Groups }\end{array}$ & $\begin{array}{l}1.6591 \\
55\end{array}$ & 1 & $\begin{array}{l}1.6591 \\
55\end{array}$ & $\begin{array}{l}10.314 \\
57\end{array}$ & $\begin{array}{l}0.0023 \\
33\end{array}$ & $\begin{array}{l}4.0383 \\
93\end{array}$ & Reject Ho \\
\hline $\begin{array}{l}\text { Within } \\
\text { Groups }\end{array}$ & $\begin{array}{l}7.8819 \\
19\end{array}$ & 49 & $\begin{array}{l}0.1608 \\
55\end{array}$ & & & & \\
\hline Total & $\begin{array}{l}9.5410 \\
74\end{array}$ & 50 & & & & & \\
\hline
\end{tabular}

The $F$ value is 10.31457 , higher than the F-critical, 4.038393 for the alpha stage of 0,05 , as can be seen. The study thus has reasons to refute the null statement and to suggest that at least one sample has substantially different means and is thus a part of a totally different community. Moreover, the p-value computed is 0.002333 , which is less than the alpha level of 0.05 ; therefore, we reject the null hypothesis, and therefore, there is sufficient evidence to conclude that not all the means are equal. As quoted by Balgiah et al.(2017), Low \& Lamb (2000) points out that the consumer's response to products is the way that customers bind the brand and control their purchasing behavior. Furthermore, Zhou and Wong (2008) stress that many buyers rely more on brand rather than product quality and make the brand more relevant than the quality of the product itself. For example, when eating out, consumers do not look at all characteristics; however, they do choose a restaurant that is built on a broad mindset towards a specific restaurant brand. Therefore, it is important to consider customer sentiments towards products. However, the main focus of the previous studies in the restaurant industry was on consumer loyalty. Customer satisfaction is a customer appraisal of a single purchase that reflects on the product or service's results, according to Bolton and Drew (1991), whereas consumer attitudes are the detailed assessment of a company.

\section{Challenges Faced by The Casual Dining Restaurants in The New Normal}

Centered on the investigator's survey, the challenges faced by the casual dining restaurant in meeting customer expectations and satisfaction, this section enumerated the challenges as provided by the customers of the casual dining restaurants in the National Capital Region. Table 7 depicts the challenges of the casual dining restaurant in the new normal. Results showed that 264 out of 432 respondents or $61 \%$, responded that safety in terms of the Inter-Agency Task Force (IATF) protocols in the new normal hindered the casual dining expectations and satisfactions. These stated the specific concerns of the respondents as such: "They need to provide the safest food and secured atmosphere at all times, they need to meet the customer confidence as a gauge to customer satisfaction and loyalty. That's why they have to change their business model to adapt to the new normal." 
Table 7 Challenges of the Casual Dining Restaurants in the New Normal in Meeting Customer Expectations and Satisfaction

\begin{tabular}{rlccc}
\hline \multicolumn{1}{c}{ Challenges } & Frequency & Percentage & Rank \\
\hline 1. Accommodation & 52 & $12 \%$ & 3 \\
2. Cleanliness & 11 & $3 \%$ & 5 \\
3. Profit & 15 & $4 \%$ & 4 \\
4. Safety and Sanitation & 264 & $61 \%$ & 1 \\
5. Services & 90 & $21 \%$ & 2 \\
Total & & 432 & $100 \%$ & \\
\hline
\end{tabular}

Note: Multiple Responses

The foodservice industry, therefore, faces problems with the appropriate brand process that can only be exacerbated with the existing state-of-the-art climate and government-setting standards. According to Sharma et al. (2020), the effect is clear from the company perspective: serious revenue declines, the vast number of staff fired, and the permanent closure of some firms. The result of this study on the challenges faced by casual dining was supported by Verdict (2020) by elaborating the assessment on the impact of the COVID-19 outbreak on foodservice operators. Telukdarie \& Mohlala (2020) also listed the global food and beverage industry as segmented based on online food chains and offline food chains in their study of the impacts of COVID-19 on the food and beverage development field and their sustainability. Offline grocery chain shops and coffee shut down completely from certain places such as North America, Europe, Asia-Pacific, and the globe had an effect on COVID-19.

\section{Proposed Strategic Brand Mechanism Framework for Casual Dining Restaurant}

The study depicted brand standard mechanism dimensions that will help the restaurant brand achieve customer brand preference. Thus, this proposed model is significant in customizing the various customer brand preference model in the foodservice industry and becomes a guiding principle among hospitality industry stakeholders. To depict the schematic model, Figure 2 presents the proposed Strategic Brand Mechanism Model for Casual Dining Restaurants. The model's Strategic Brand Mechanism reflects the standard brand dimension necessary for the measurement of consumer brand choice. The three aspects of the five dimensions of the brand are customer expectations, customer attitudes, and employee engagement. It can be useful for combining education and training, aligning it with labor market needs, as well as fostering versatility and openness for restaurant brands, particularly for new market players. The model is composed of six brand dimensions, namely Brand Management, Brand Service Performance, Brand Safety Protocols and Sanitation, Brand Technical and Operational Design, Brand Menu Selection and Pricing, and Brand Awareness and Sustainability as part of Strategic Brand Mechanism Model for Casual Dining Restaurants.

Brand Management is a brand-standard mechanism that helps people to handle and manage the physical and/or technological functions of a brand-restaurant organization, especially in relation to development and production. Includes general management principles and manufacturing processes guidance, facility management, facilities maintenance, industrial legislation, labor relations and skilled trade oversight, company policy, system review, production and cost control analysis, and material planning, particularly for consumer desires. Brands provide a strong impact on the commitment of customers, industry competition, and business management. Clear brand identity in the market distinguishes goods of a company from their rivals and builds brand loyalty towards products or services of a company. Brand Service Performance, defined as good, friendly, fair, democratic, health-care, and speedy, are evidence of the efficiency of brand service performance. Most food services networks market their process, behavior, aura, and charisma. Greater focus on service would improve the target market participation and will enable brand-restaurant operations to be more effective. It is impossible to calculate the quality of service and complicated since it is 
immaterial. The intangible factors may be the productivity of managers, their reaction to customer concerns or issues. The service environment plays a key role in determining how excellent service output is delivered, as it acquires workers' expertise in terms of corporate reality in the delivery of services. It also affects the motivation of employees in terms of service behavior. If workers have outstanding internal service efficiency, they would most definitely be able to offer excellent quality externally to the organization. A good service environment contributes to the consistency of service.

Figure 2 Proposed Strategic Brand Mechanism Model for Casual Dining Restaurants

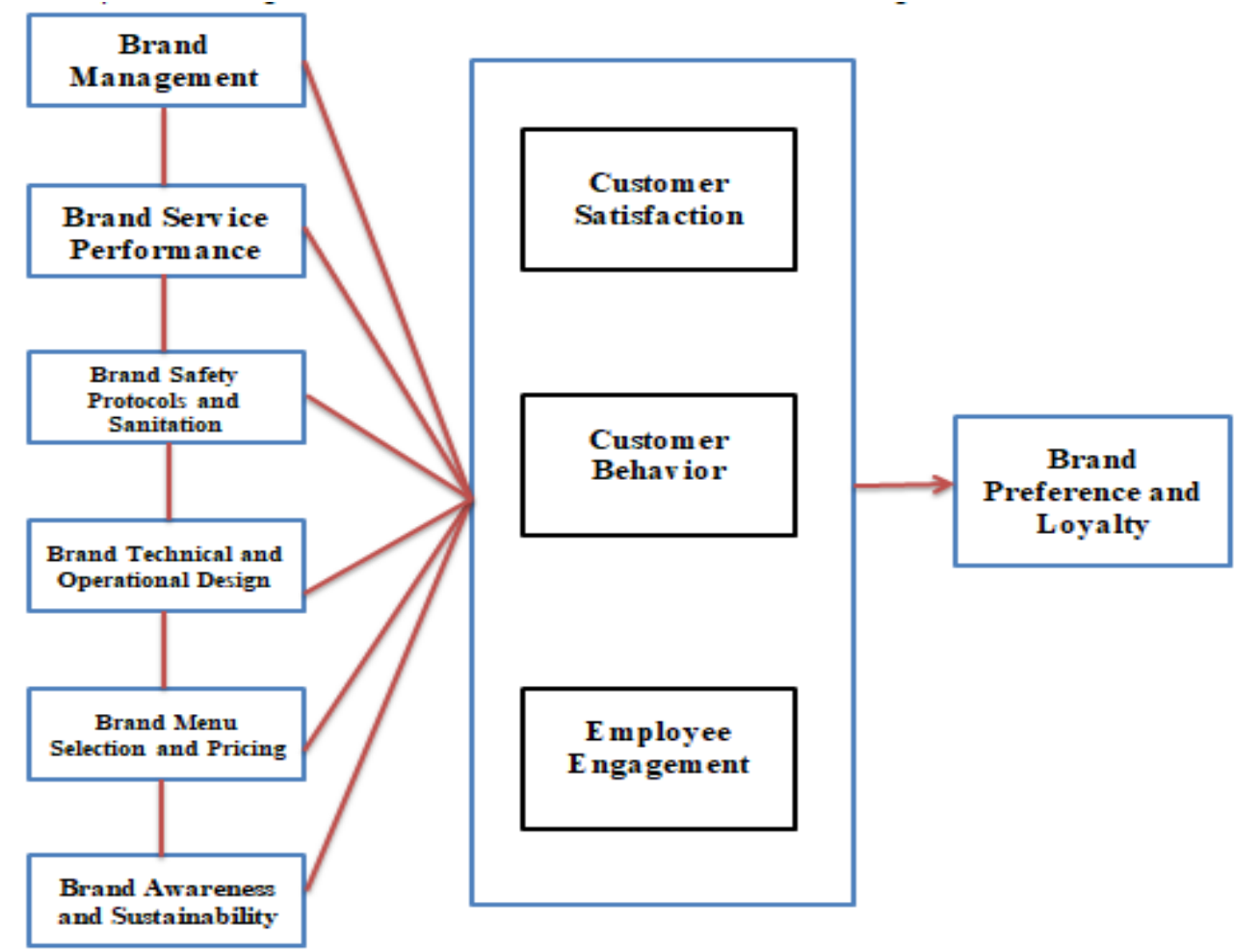

In the light of ways to avoid infection, food-sane facilities were listed, and some foodborne pathogens shared their fears and how best they would handle consumer interactions and see if a complaint was really a result of proceedings. Making HACCP is a further example of a food challenge challenging food labels within a restaurant brand mechanism working in separate food markets, for example, large-volume operations without the use of pre-produced or frozen food. If each employee has a well-trained program of workshops on aspects of food safety, their awareness of food safety and health will undoubtedly be improved. That is why Brand Safety and Protocols were included in the proposed strategic brand mechanism model for casual dining restaurants.

The setting and the architecture are a portion of the brand itself that gives an idea of the particular venue which includes the dining environment construction, design, interior design and paint, texture and food. The spatial arrangement of the sitting, the different interiors and environmental melodies suitability are the key in ensuring the happiness and preferential care of our customers. This pertains to the importance of Brand Technical and Operational Design as part of the model. Brand Menu Selection and Pricing is another brand mechanism dimension that is very significant to consider in this time of pandemic situation approaching the new normal of the foodservice industry. The restaurant must be planned to benefit consumers by offering a variety of foods and plates and rates that allow them to purchase safe and affordable foods at reasonable prices. The best quality at the right price is an essential mix. One of the most urgent reasons that enable clients to return to their food services company and to gain customer loyalty and choice is the best value for money spent. Customers continue to shop at affordable prices for food and drink. The expense is the key variable of the restaurant's service. Similarly, they have stated that if food and drink costs for consumers are too high, customers can buy food and drink from cheaper brand 
names. The good food and drink variety is an important factor in the satisfaction of our customers. Customer price sensitivity varies greatly depending on the market and customer segment of the particular brand of the casual dining restaurant. The most successful business would be willing to demonstrate empathy and justify how much benefit they have in comparison to the next-best substitutes. The salesforce can need updated negotiating, value marketing, and pricing preparation. Casual Dining Restaurants must conduct new pricing-sensitivity testing and market price tests right away to better understand shifting price points, particularly for higher-volume goods and services. The way pricing reductions are implemented may have a significant impact on a company's ability to retain and grow value over time.

Brand Awareness and Sustainability is the last dimension for the proposed brand mechanism model. This high-quality performance method involves each one on the market by regular working place checking and daily screening. In this way, we will establish collaboration and contact strategies for all to join. The sustainability tactics of the brand for restaurant compliance are calculated. It is the most important brand norm process, as this clearly implies the effectiveness of the restaurant brand's production and service quality. This standard mechanism concerns strategic business strategy for the continued growth of the brand targeted at the local market as a whole. Sustainable brand management necessitates a systemic redesign of business concepts and a synergetic approach; in other terms, it necessitates the involvement of various parties towards a shared target, with the customer being the ultimate arbiter of whether or not a given business model would be approved. There are two simple and effective approaches to assess the brand's awareness. First, check how much traffic your website receives on a regular, monthly, or annual basis, and see how much of those users are going straight to your site by typing in your website's URL. This indicates that the company is well-known and well-recognized. Another approach to gauge brand interest is to look at how many customers are looking for the company's logo on the internet. This is also another positive example of consumer name awareness. It's crucial to monitor the brand's popularity over time to see how your marketing strategies influence brand recognition. This will assist you in concentrating your marketing efforts for full effect.

\section{Conclusion}

Providing client service in a vibrant atmosphere guarantees a continual enhancement of customer engagement and loyalty. Evidence shows, however, that satisfying buyers are not required to retain them, as many firms already defect happy customers at high rates. According to Euromonitor International (2020), competition has increased in the Philippines consumer services sector. The rise in competitiveness across categories was particularly noteworthy as the food customer service operators were working to respond to the growing demand of consumers. Furthermore, as market foodservice companies sought to meet the growing need for flexibility by busy customers, the usage of distribution services grew, increasing direct rivalry between providers across categories at the end of the review period.

The ongoing expansion of chained operators, especially in the limited-service and full-service restaurant categories, is expected to drive continued growth in the Philippine consumer foodservice industry from 2019 to 2024. The expansion of chains into provincial regions, aided by franchising strategies, will play a key role in driving development. Furthermore, the increasing demand for convenience among consumers living hectic urban lifestyles is expected to help expansion. Over the forecast era, this is projected to continue to accelerate the growth and acceptance of delivery services across all customer foodservice categories. As players adopt new goods, formats, facilities, and technical resources in response to changing market demand, the lines between existing consumer foodservice segments are likely to become increasingly blurred. (Euromonitor International, 2020).

Brand standards have been a core research area and recognize that satisfaction by itself does not guarantee significant consumer actions such as loyalty. The foodservice business is conditional upon 
a combination of goods/service characteristics that serve to optimize consumer satisfaction. Other consumer satisfaction strategies should be calculated from a cost/benefit standpoint, a productivity yield, a readiness to copy competition, and an enterprise's willingness to fulfill increasing requests for each strategy. The finding denotes that all the indicators in the corporate social responsibility driver are "Very Satisfactory," which means that the casual dining establishment follows basic requirements for brand performance. The finding also denotes that all the indicators in the Environmental Marketing driver are "Very Satisfactory," which means that the casual dining establishment follows basic requirements for brand performance. The majority of the indicators in an Innovation are "Excellent," which means that the casual dining establishment is outstanding in terms of brand performance. The casual dining establishments are superior in terms of brand performance for service quality. In terms of standard of operation, service level, product quality, atmosphere, and price, the restaurant, from fast food to fine dining, plays a significant role. Menu variety and cleanliness were also attributed to the service quality.

It is therefore recommended that the casual dining industry can elaborate the innovative strategies appropriate to the demand of the new normal in terms of customer satisfaction to maintain sustainability and to further test the level of significance in terms of the relationship towards brand preference. For the service quality, it is recommended to adopt a variety of menus appropriate to the needs of the casual dining restaurant in line with the current situation of the COVID-19 pandemic that is healthy but affordable. Statistically non-significant relationship is found between the drivers of brand performance and customer attitudes towards brand preference in terms of Corporate Social Responsibility Practices, Marketing Practices, Innovation and Service Quality given in the study. The study has shown that the null statement of the large disparity between the consumer profiles and the customer profile is rejected and says that at least one of the two samples has a substantially different meaning. It is therefore recommended to use the proposed Strategic Brand Mechanism Model, which aimed to align the standard operating procedures of all the casual dining restaurants as a whole, most especially in this time of pandemic situation. In meeting customer expectations and satisfaction, casual dining restaurants can be able to sustain and maintain their brand standing in the market using the proposed strategic brand mechanism.

Finally, the well-being and hygiene of casual restaurant respondents have been the most difficult in light of the current standard customer support and satisfaction. It is also inferred that the preferences and happiness of the consumer impact. It is recommended that casual dining restaurants should make a safety and sanitation intervention and strategic implementation that will strengthen their brand image to lessen or limit the challenges faced by the casual dining restaurants.

\section{References}

1. Ahorro, A. M. T., David, M. R. T., Molina, J. M. V., Pangilinan, A. B. Y., \& Arcinas, M. M. (2021). Correlations between the Senior High School Grade 12 Students' Perception of School Classroom Climate and Compliance to School Classroom Norms in a Private University in Manila, Philippines. International Journal of Multidisciplinary: Applied Business and Education Research, 2(4), 274-284.

2. Ar, I. M. (2012). The impact of green product innovation on firm performance and competitive capability: the moderating role of managerial environmental concern. Procedia-Social and Behavioral Sciences, 62, 854-864.

3. Arcinas, M. M. (2021). A Blockchain Based Framework For Securing Students Educational Data. LINGUISTICA ANTVERPIENSIA, 4475-4484.

4. Baker, W. E., \& Sinkula, J. M. (2005). Market orientation and the new product paradox. Journal of Product Innovation Management, 22(6), 483-502.

5. Baumgarth, C., \& Schmidt, M. (2010). How strong is the business-to-business brand in the workforce? An empirically-tested model of 'internal brand equity'in a business-to-business setting. Industrial Marketing Management, 39(8), 1250-1260. 
6. Bhatti, I. A., Parveen, S., \& Arshad, S. (2011). Effect of perceived corporate brand on customers' attitude towards Islamic banking. International Journal of Contemporary Business Studies, 2(2), 54-68.

7. Chan, H.K., He, H. and Wang, W.Y. (2012). Green marketing and its impact on supply chain management in industrial markets. Industrial Marketing Management, Vol. 41 No. 4, pp. 557-562. https://doi.org/10.1016/j.indmarman.2012.04.002

8. Chang, C. C., \& Carballo, C. F. S. (2011). Energy conservation and sustainable economic growth: The case of Latin America and the Caribbean. Energy policy, 39(7), 4215-4221.

9. Charernnit, K., Alhourani, A. Q., Arcinas, M. M., Velasco, L. G., \& Alhourani, A. Q. Cognitive and Attitudinal Effects of Jigsaw Technique as a Collaborative Learning Strategy in Literature Teaching in the Philipines.

10.Chiou, T.Y., Chan, H.K., Lettice, F. and Chung, S.H. (2011). The influence of greening the suppliers and green innovation on environmental performance and competitive advantage in Taiwan. Transportation Research Part E: Logistics and Transportation Review, Vol. 47 No. 6, pp. 822-836. https://doi.org/10.1016/j.tre.2011.05.016

11.Danish Habib, M., \& Attiq, S. (2020). A model and empirical examination of influencing factors of customer satisfaction and service performance through interactional quality. Business \& Economic Review, 12(1), 119-138. https://doi.org/10.22547/ber/12.1.6

12.De Souza, R., Parveen, R., Chupradit, S., Velasco, L. G., Arcinas, M., Tabuena, A. C., ... \& Ventayen, R. J. M. (2021). Language Teachers' Pedagogical Orientations in Integrating Technology in the Online Classroom: Its Effect on Students Motivation and Engagement. Turkish Journal of Computer and Mathematics Education, 12.

13.DiPietro, R. B., \& Gregory, S. (2012). Customer perceptions regarding green restaurant practices: a comparison between fast food and upscale casual restaurants. FIU Hospitality Review, 30(1), 1-22.

14.DiPietro, R. B., Cao, Y., \& Partlow, C. (2013). Green practices in upscale foodservice operations: Customer perceptions and purchase intentions. International Journal of Contemporary Hospitality Management.

15.DiPrieto, R. (2017). Restaurant and foodservice research: A critical reflection behind and an optimistic look ahead. Journal of Contemporary Hospitality Management. International Journal of Contemporary Hospitality Management, 29(4), 1203-1234. https://doi.org/10.1108/IJCHM-012016-0046

16.Dutta, M. J. (2008). Communicating health: A culture-centered approach. Polity.

17.Euromonitor International (2020). Consumer Foodservice in the Philippines https://www-portaleuromonitor-com.dlsu.idm.oclc.org/portal/analysis/tab

18.Fraj-Andrés, E., Martinez-Salinas, E. and Matute-Vallejo, J. (2009). A multidimensional approach to the influence of environmental marketing and orientation on the firm's organizational performance. Journal of Business Ethics, Vol. 88 No. 2, pp. 263-286.

https://doi.org/10.1007/s10551-008-9962-2

19.Gheribi, E. (2017). The Activities of Foodservice Companies in the Area of Corporate Social Responsibility - on the Example of International Fast Food Chain. Journal of Positive Management Vol. 8 No.1 pp 64-77. http://dx.doi.org/10.12775/JPM.2017.005

20.Gheribi, E., Altuntas, G., \& Bonadonna, A. (2018). Innovations in the foodservice business in large Polish cities. Acta Scientiarum Polonorum. Oeconomia, 17(4).

21.Han, H., \& Ryu, K. (2009). The roles of the physical environment, price perception, and customer satisfaction in determining customer loyalty in the restaurant industry. Journal of Hospitality and Tourism Research, 33(4), 487-510. https://doi.org/10.1177\%2F1096348009344212

22.Harrington, K., Flint, A., \& Healey, M. (2014). Engagement through partnership: Students as partners in learning and teaching in higher education.

23. Harrington, R.J. and Ottenbacher, M.C. (2013). Managing the culinary innovation process: the case of new product development. Journal of Culinary Science \& Technology, Vol. 11 No. 1, pp. 4-18. https://doi.org/10.1080/15428052.2012.754724 
24.He, H. and Harris, L. (2020). The Impact of Covid-19 Pandemic on Corporate Social Responsibility and Marketing Philosophy. Journal of Business Research. Vol. 116 pp 176-182. https://doi.org/10.1016/j.jbusres.2020.05.030

25.Hu, B. (2014). Linking business models with technological innovation performance through organizational learning. European management journal, 32(4), 587-595.

26.Hull, C.E. and Lio, B.H. (2006). Innovation in non-profit and for-profit organizations: visionary, strategic, and financial considerations. Journal of Change Management, Vol. 6 No. 1, pp. 53-66. https://doi.org/10.1080/14697010500523418

27.Hwang, J. (2011). Brand Preference And Its Impacts on Customer Share of Visits And WordOfMouth Intention: An Empirical Study In The Full-Service Restaurant Segment. UMI Dissertation Publishing, 86-90.

https://www.proquest.com/openview/0b09b27e8006a379eb80d8d60927924e/1?pq-

origsite $=$ gscholar $\& \mathrm{cbl}=18750 \&$ diss $=y$

28. Iyer, P., Davari, A., Srivastava, S., \& Paswan, A. K. (2020). Market orientation, brand management processes and brand performance. Journal of Product \& Brand Management, 30(2), 197-214. https://doi.org/10.1108/jpbm-08-2019-2530

29.Jacksonville (2020). Impact of COVID 19 on food \& beverages industry market. Copyright Close-Up Media, Inc. Apr 20, 2020

30.Jang, H., Olfman, L., Ko, I., Koh, J., \& Kim, K. (2008). The influence of on-line brand community characteristics on community commitment and brand loyalty. International journal of electronic commerce, 12(3), 57-80.

31.Kim, H., Park, K., \& Ryu, D. (2015). Corporate Environmental Responsibility: A Legal Origins Perspective. Journal of Business Ethics, 140(3), 381-402. https://doi.org/10.1007/s10551-0152641-1 https://doi.org/10.1007/s10551-015-2641-1

32.Kim, M. Et al. (2017). Drivers of perceived market and eco-performance in the foodservice industry. International Journal of Contemporary Hospitality Management, Vol. 30 No. 2, 2018 pp. 720-739. https://doi.org/10.1108/IJCHM-07-2016-0361

33.Kim, W. G., Li, J. J., \& Brymer, R. A. (2016). The impact of social media reviews on restaurant performance: The moderating role of excellence certificate. International Journal of Hospitality Management, 55, 41-51.

34.Kim, Y. (2015). Consumer Responses to the Food Industry's Proactive and Passive Environmental CSR, Factoring in Price as CSR Trade-off. Journal Business Ethics Vol. 140 pp. 307-321. https://doi.org/10.1007/s10551-015-2671-8

35.Kumar, S., \& Chachal, N. (2017). Food Service Quality in IRCTC Food Outlets: A Study of Delhi (NCR) Region. International Journal of Hospitality and Tourism Systems, 10(1), 45.

36.Laužikas, M., Miliūtè, A. è., Tranavičius, L., \& Kičiatovas, E. (2016). Service Innovation Commercialization Factors in the Fast Food Industry. Entrepreneurship and Sustainability Issues, 4(2), 108-128. https://doi.org/10.9770/jesi.2016.4.2(1)

37.Lopez, K. R. B., Gaticales, N. P., Provido, A. V. C., Santelices, S. M. B., \& Arcinas, M. M. (2021). Social Contagion of Astrology in the Social Media amid COVID-19 Pandemic. International Journal of Multidisciplinary: Applied Business and Education Research, 2(4), 349-363.

38. Magulod Jr, G. C. (2017). Factors of school effectiveness and performance of selected public and private elementary schools: implications on educational planning in the Philippines. Asia Pacific Journal of Multidisciplinary Research, 5(1), 73-83.

39.Magulod Jr, G. C. (2019). Learning styles, study habits and academic performance of Filipino University students in applied science courses: Implications for instruction. JOTSE: Journal of Technology and Science Education, 9(2), 184-198.

40.Magulod, G. C., Capulso, L. B., Dasig, J. P., Baluyot, M. B. B., Nisperos, J. N. S., Reyes-Chua, E., \& Chupradit, S. (2021). Attainment of the Immediate Program Graduate Attributes and Learning Outcomes of Teacher Candidates towards Global Competence Initiatives. International Journal of Learning, Teaching and Educational Research, 19(12). 
41.Magulod, G. C., Capulso, L. B., Tabiolo, C. D. L., Luza, M. N., \& Ramada, M. G. C. (2020). Use of technology-based tools in ensuring quality of publishable journal articles. Int $J$ Learn Teach Educ Res, 19, 145-162.

42.Molina-Azorín, J.F., Claver-Cortés, E., López-Gamero, M.D. and Tarí, J.J. (2009). Green management and financial performance: a literature review. Management Decision, Vol. 47 No. 7, pp. 1080-1100. https://doi.org/10.1108/00251740910978313

43.Namkung, Y. and Jang, S.C. (2013). Effects of restaurant green practices on Brand equity formation: do green practices really matter? International Journal of Hospitality Management, Vol. 33, pp. 85-95. https://doi.org/10.1016/j.ijhm.2012.06.006

44.Namkung, Y., \& Jang, S. (2007). Does food quality really matter in restaurants? Its impact on customer satisfaction and behavioral intentions. Journal of Hospitality \& Tourism Research, 31(3), 387-409.

45.Nowak, L.I., Fucciolo, K. and Ponsford, B.S. (2015). Pro-environmental strategies for small businesses: factors affecting consumer trust and responsibility. Journal of Small Business Strategy, Vol. 10 No. 2, pp. 78-85.

46.Nuncio, R. V., Arcinas, M. M., Lucas, R. I. G., Alontaga, J. V. Q., Neri, S. G. T., \& Carpena, J. M. (2020). An E-learning outreach program for public schools: Findings and lessons learned based on a pilot program in Makati City and Cabuyao City, Laguna, Philippines. Evaluation and Program Planning, 82, 101846.

47.Ottenbacher, M. C., \& Harrington, R. J. (2013). A case study of a culinary tourism campaign in Germany: Implications for strategy making and successful implementation. Journal of Hospitality \& Tourism Research, 37(1), 3-28.

48.Ottenbacher, M.C. (2007). Innovation management in the hospitality industry: different strategies for achieving success. Journal of Hospitality \& Tourism Research, Vol. 31 No. 4, pp. 431-454. https://doi.org/10.1177\%2F1096348007302352

49.Pan, C.-L., Yu, L., Lin, Z., Li, J., \& Pan, Y.-C. (2020). Scientometric Analysis of Corporate Social Responsibility, Corporate Social Performance and Financial Performance Based on Corporate Governance. E3S Web of Conferences, 214, 03014. https://doi.org/10.1051/e3sconf/202021403014

50.Peattie, K. (2001). Towards sustainability: the third age of green marketing. The Marketing Review, Vol. 2 No. 2, pp. 129-146. https://doi.org/10.1362/1469347012569869

51.Pujari, D., Wright, G. and Peattie, K. (2003). Green and competitive: influences on environmental new product development performance. Journal of Business Research, Vol. 56 No. 8, pp. 657-671. https://doi.org/10.1016/S0148-2963(01)00310-1

52.Ruiz-Molina et. al. (2010). Good environmental practices for hospitality and tourism: The role of information and communication technologies. Management of Environmental Quality: An International Journal Vol. 21 No. 4, 2010 pp. 464-476. https://doi.org/10.1108/14777831011049106

53.Ruiz-Molina, M. E., Gil-Saura, I., \& Berenguer-Contrí, G. (2014). Information and communication technology as a differentiation tool in restaurants. Journal of Foodservice Business Research, $17(5), 410-428$.

54.Ryu, K., \& Jang, S. C. (2008). DINESCAPE: A scale for customers" perception of dining environments. Journal of Foodservice Business Research, 11(1), 2-22. https://doi.org/10.1080/15378020801926551

55.Ryu, K., Lee, H., Kim, W., (2012). The Influence Of The Quality Of The Physical Environment, Food, And Service On Restaurant Image, Customer Perceived Value, Customer Satisfaction, And Behavioral Intentions. International Journal of Contemporary Hospitality Management, Vol. 24 Issue: 2, pp.200. https://doi.org/10.1108/09596111211206141

56.Sharma, A., Cosguner, K., Sharma, T. K., \& Motiani, M. (2020). Channel Intermediaries and Manufacturer Performance: An Exploratory Investigation in an Emerging Market. Journal of Retailing. 
57.Su, H. C., \& Linderman, K. (2016). An empirical investigation in sustaining high-quality performance. Decision Sciences, 47(5), 787-819.

58.Telukdarie, A., Munsamy, M., \& Mohlala, P. (2020). Analysis of the Impact of COVID-19 on the Food and Beverages Manufacturing Sector. Sustainability, 12(22), 9331.

https://doi.org/10.3390/su12229331

59.Telukdarie, A., Munsamy, M., \& Mohlala, P. (2020). Analysis of the Impact of COVID-19 on the Food and Beverages Manufacturing Sector. Sustainability, 12(22), 9331.

60.Verdict Media Limited. (2020). COVID-19 pandemic to have a devastating impact on foodservice operators: Poll. Retrieved from https://www.verdictfoodservice.com/news/covid-19-impactdevastating-on-food-service-operators/ on October 2, 2020

61.Vu, H. M., Chan, H. K., Lim, M. K., \& Chiu, A. S. F. (2017). Measuring business sustainability in food service operations: a case study in the fast food industry. Benchmarking: An International Journal, 24(4), 1037-1051. https://doi.org/10.1108/bij-04-2015-0030

62.Willard, M., \& Hitchcock, D. (2009). The business guide to sustainability: Practical strategies and tools for organizations. Routledge.

63.Zhou, L., \& Wong, A. (2008). Exploring the influence of product conspicuousness and social compliance on purchasing motives of young Chinese consumers for foreign brands. Journal of Consumer Behavior, 7(6), 470-483. https://doi.org/10.1002/cb.265 